\title{
PROFIL PENDERITA PENYAKIT KUSTA DI RUMAH SAKIT KUSTA KEDIRI PERIODE JANUARI 2010 SAMPAI DESEMBER 2010
}

\author{
Annisa Qoyyum Nabila1, Sri Adila Nurainiwati², Djaka Handaja ${ }^{3}$
}

Fakultas Kedokteran Universitas Muhammadiyah Malang, Jl. Bendungan Sutami No. 188A, Kota Malang, 65145, Indonesia 0341-551149

\begin{abstract}
ABSTRAK
PROFIL PENDERITA PENYAKIT KUSTA DI RUMAH SAKIT KUSTA KEDIRI PERIODE JANUARI 2010 SAMPAI DESEMBER 2010. Latar Belakang: Kusta adalah penyakit infeksi kronis yang disebabkan oleh Mycobacterium leprae. Kusta menyebabkan masalah kompleks, meliputi masalah medis, ekonomi, dan sosial. Tujuan: Penelitian ini bertujuan mengetahui profil penderita kusta di Rumah Sakit Kusta Kediri periode Januari 2010 sampai Desember 2010. Metode: Penelitian ini menggunakan metode deskriptif observasional dengan total sampling. Hasil: Diperoleh 120 (6.12\%) penderita kusta baru dari 1960 kunjungan. Jenis kelamin terbanyak adalah laki-laki (75\%). Kelompok usia terbanyak adalah 35-44 tahun (26.67\%). Pekerjaan terbanyak adalah swasta (43.33\%). Penderita terbanyak dari Kediri (46.67\%). Tipe kusta terbanyak tipe MB (91.67\%). Gambaran klinis kusta terbanyak makula (88.33\%) dan anastesi (83.33\%). Predileksi pembesaran saraf terbanyak pada saraf tibialis posterior (65.41\%). Kecacatan terbanyak pada kaki. Tingkat kecacatan mata paling banyak tingkat 0 (95\%). Tingkat kecacatan tangan terbanyak tingkat 0 (55.41\%). Tingkat kecacatan kaki paling banyak tingkat 1 (44.58\%). Reaksi kusta paling banyak adalah tidak terjadi reaksi (79.17\%). Kesimpulan: Penderita kusta terbanyak adalah lakilaki. Kelompok usia terbanyak adalah 35-44 tahun. Tipe kusta yang paling banyak adalah tipe MB. Gambaran klinis yang sering ditemukan adalah makula dan anastesi. Kecacatan terbanyak terdapat pada kaki. Tingkat kecacatan pada mata yang terbanyak adalah tingkat 0 , pada tangan tingkat 0 , dan pada kaki tingkat 1 .
\end{abstract}

\section{ABSTRACT}

THE PROFILE OF LEPROSY PATIENT IN KEDIRI LEPROSY HOSPITAL DURING JANUARY 2010 UNTIL DESEMBER 2010. Background: Leprosy is chronic infection disease caused by Mycobacterium leprae. Leprosy causes complex problem, not only medical problem but also social and economic problem. Objective: This research investigate the profile of leprosy patient in Kediri Leprosy Hospital during January 2010 until December 2010. Method: This research used observational descriptive method with total sampling g technique. Result: From this research was found 120 (6.12\%) new leprosy patient from 1960 total patient visit. The most patient were male (75\%). The most age group were 35-44 years old (26.67\%). Majority the jobs of leprosy patient were private worker (43.33\%). The most patient were came from Kediri (46.67\%). The most leprosy type of patient were MB type $(91.67 \%)$. The most clinical manifestation that found were macula $(88.33 \%)$ and anesthetic $(83.33 \%)$. The most nerve enlargement predilection were posterior tibia nerve (65.41\%). The most impairment were in foot. The impairment grade in eye were 0 (95\%). The most impairment grade in hand were grade 0 (55.41\%). The most impairment grade in foot were $1(44.58 \%)$. The most leprosy reaction were no leprosy reaction (79.17\%). Conclusion: The most leprosy patient were male. The most age group were 35-44 years old. The most leprosy type were MB type. The most clinical manifestation were macula and anesthetic. The most impairment were in foot. The most impairment grade in eye were grade 0 . The most impairment grade in hand were grade 0 . The most impairment grade in foot were grade 1.

Key words: Profile, leprosy, Kediri Leprosy Hospital.

\section{PENDAHULUAN}

Penyakit kusta adalah penyakit kronis yang disebabkan oleh bakteri Mycobacterium leprae yang menyerang saraf tepi, kulit, mukosa mulut, saluran nafas bagian atas, otot, tulang, dan testis (Amirudin, 2000). Kusta memiliki tiga gambaran klinis khas yang disebut cardinal sign yaitu adanya lesi yang mati rasa, kerusakan saraf tepi, dan adanya bakteri basil tahan asam (Amirudin, 2003). Faktor-faktor yang mempengaruhi penyebaran penyakit kusta adalah patogenesis bakteri, cara penularan, keadaan sosial dan ekonomi, lingkungan, dan imunitas individu (Kosasih, 2007). Klasifikasi kusta menurut World Health Organization (WHO) tahun 1997 dibagi menjadi 3 berdasarkan jumlah lesi dan pemeriksaan hapusan kulit, yaitu: pausibasiler lesi tunggal, pausibasiler, dan multibasiler (WHO, 1997). Kusta menyebabkan berbagai macam kerusakan pada tubuh berupa hilangnya sensibilitas saraf dan kecacatan anggota tubuh. Tingkat kecacatan dibagi menjadi 3, yaitu tingkat 0,1, dan 2 (Srinivasan, 1994).

Penyakit kusta merupakan penyakit menular yang menimbulkan masalah kompleks, tidak hanya dari segi medis tetapi juga masalah sosial dan ekonomi yang terjadi akibat stigma buruk masyarakat terhadap kecacatan penderita 
kusta. Stigma buruk masyarakat timbul akibat kesalahan persepsi dan pengetahuan yang sempit mengenai kusta sehingga penderita kusta mengalami diskriminasi dalam masyarakat dan kesulitan mendapat pekerjaan (Puspita, 2011). Kusta merupakan salah satu masalah kesehatan di dunia terutama bagi negara-negara berkembang. Pada tahun 2009, kasus baru kusta terbanyak di dunia terdapat di India yaitu sejumlah 133.717 kasus, diikuti Brazil sejumlah 37.610 kasus dan Indonesia di posisi ketiga sejumlah 17.260 kasus (WHO, 2010). Pada tahun 1991 World Health Assembly telah mengeluarkan resolusi eliminasi kusta tahun 2000 dengan target prevalence rate kurang dari 1/10.000 penduduk. Indonesia secara nasional telah mencapai target sejak bulan Juni 2000 dengan prevalence rate 0,84/10.000 penduduk, namun beberapa provinsi belum memenuhi target tersebut, salah satunya provinsi Jawa Timur (Depkes RI, 2007). Jawa Timur menduduki peringkat pertama di Indonesia sebagai provinsi dengan kasus kusta tertinggi yaitu 30 persen dari keseluruhan kasus kusta di Indonesia. Prevalence rate kusta tahun 2009 di Jawa Timur sebesar 1,64 per 10.000 penduduk, dengan penderita kusta pausibasiler sejumlah 713 orang dan penderita kusta multibasiler 3.971 orang (Dinkes Jatim, 2010).

Tujuan umum penelitian ini adalah mengetahui profil penderita kusta di Rumah Sakit Kusta Kediri. Selain itu penelitian ini dapat mengetahui jumlah penderita kusta dengan kunjungan pertama di Rumah Sakit Kusta Kediri. Selain itu dapat diketahui identitas penderita, distribusi tipe kusta menurut klasifikasi WHO, dan distribusi gambaran klinis penderita. Penelitian ini juga dapat menggambarkan predileksi pembesaran saraf tepi, tingkat kecacatan, dan reaksi kusta penderita kusta di Rumah Sakit Kusta Kediri. Penelitian ini diharapkan dapat memberikan informasi kepada peneliti, tenaga medis, dan masyarakat mengenai jumlah kasus baru kusta dan profil penderita penyakit kusta tahun 2010. Selain itu penelitian ini dapat memberikan informasi kepada tenaga medis untuk meningkatkan pelayanan dalam mendeteksi kusta sejak dini sehingga mencegah kecacatan lebih lanjut.

\section{METODE}

Penelitian ini merupakan penelitian deskriptif observasional dengan pendekatan studi kasus. Penelitian dilakukan di bagian rekam medik Rumah Sakit Kusta Kediri pada bulan Januari dan Februari 2012.

Populasi penelitian ini adalah penderita yang berkunjung ke Rumah Sakit Kusta Kediri periode 1 Januari sampai 31 Desember 2010. Sedangkan sampel penelitian adalah penderita kusta dengan kunjungan pertama pada periode 1 Januari sampai 31 Desember 2010 yang diambil dari rekam medis Rumah Sakit Kusta Kediri. Teknik pengambilan sampel yang digunakan adalah non random sampling dengan total sampling.

Karakteristik pengambilan sampel meliputi kriteria inklusi dan eksklusi. Kriteria inklusi penelitian ini adalah penderita kusta dengan kunjungan pertama yang mempunyai data identitas (jenis kelamin, usia, pekerjaan, daerah asal), tipe kusta, gambaran klinis, predileksi pembesaran saraf, tingkat kecacatan, dan reaksi kusta. Kriteria eksklusi adalah penderita dengan data yang tidak lengkap.

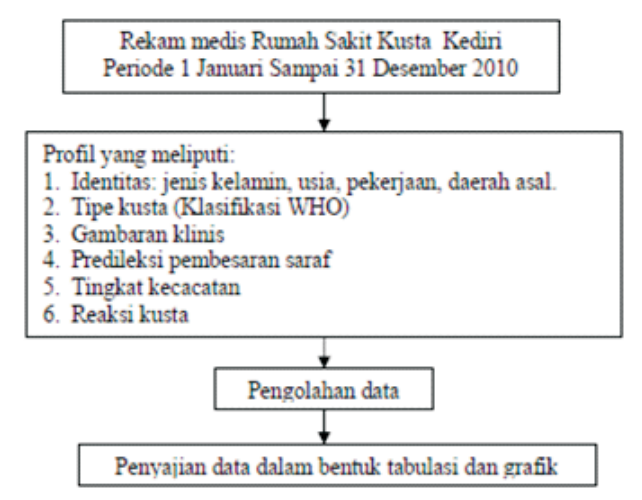

Gambar 1. Alur penelitian

Hasil penelitian berupa data yang didapatkan dari rekam medis disusun dalam bentuk tabel lalu dikelompokkan berdasarkan distribusinya dan dilakukan penghitungan frekuensi tiap-tiap distribusi kemudian data disajikan dalam bentuk grafik dan tabel yang kemudian dinarasikan.

\section{HASIL DAN PEMBAHASAN}

Dari penelitian yang telah dilakukan pada bulan Januari 2012 sampai Februari 2012 didapatkan 120 (6.12\%) penderita kusta baru dari total angka kunjungan 1.960 pasien di Rumah Sakit Kusta Kediri pada periode Januari 2010 sampai Desember 2010. Data yang diperoleh dari penelitian kemudian dideskripsikan dalam bentuk tabel.

\section{Gambaran Identitas Penderita Kusta}

\section{Distribusi Jenis Kelamin Penderita Baru Kusta}

Karakteristik penderita kusta berdasarkan jenis kelamin dari data diatas dapat diketahui bahwa mayoritas penderita kusta berjenis kelamin laki-laki yaitu sejumlah 90 penderita (75\%), sedangkan jenis kelamin perempuan sejumlah 30 penderita $(25 \%)$.

Tabel 1. Distribusi Jenis Kelamin Penderita Baru Kusta

\begin{tabular}{ccc}
\hline Jenis kelamin & Frekuensi & Persentase \\
\hline Laki-laki & 90 & 75 \\
\hline Perempuan & 30 & 25 \\
Total & 120 & 100 \\
\hline
\end{tabular}

\section{Distribusi Usia Penderita Baru Kusta}

Berdasarkan hasil penelitian, diperoleh data usia penderita kusta termuda yaitu usia 5 tahun, penderita kusta tertua yaitu usia 90 tahun dan kelompok usia terbanyak yaitu kelompok usia 35-44 dengan jumlah penderita 32 penderita $(26.67 \%)$. 
Tabel 2. Distribusi Usia Penderita Baru Kusta

\begin{tabular}{ccc}
\hline Usia & Frekuensi & Persentase \\
0-4 tahun & 0 & $0 \%$ \\
\hline 5-9 tahun & 1 & 0.83 \\
10-14 tahun & 3 & 2.50 \\
15-24 tahun & 16 & 13.33 \\
25-34 tahun & 18 & 15 \\
\hline 35-44 tahun & 32 & 26.67 \\
\hline 45-54 tahun & 21 & 17.50 \\
\hline 55-64 tahun & 17 & 14.17 \\
\hline 65 tahun & 12 & 10 \\
\hline Total & 120 & 100 \\
\hline
\end{tabular}

\section{Distribusi Pekerjaan Penderita Baru Kusta}

Berdasarkan hasil penelitian, diperoleh data pekerjaan penderita kusta terbanyak adalah swasta dengan jumlah 52 penderita $(43.33 \%)$, sedangkan pekerjaan paling sedikit adalah pegawai negeri sipil yaitu sejumlah 2 penderita $(1.67 \%)$.

Tabel 3. Distribusi Pekerjaan Penderita Baru Kusta

\begin{tabular}{lcc}
\hline \multicolumn{1}{c}{ Pekerjaan } & Frekuensi & Persentase \\
$\begin{array}{l}\text { Pegawai Negeri } \\
\text { Sipil }\end{array}$ & 2 & 1.67 \\
Swasta & 52 & 43.33 \\
\hline Petani & 31 & 25.83 \\
\hline Pelajar & 18 & 15 \\
\hline Tidak bekerja & 17 & 14.17 \\
\hline Total & 120 & 100
\end{tabular}

\section{Distribusi Daerah Asal Penderita Baru Kusta}

Karakteristik penderita kusta berdasarkan daerah asal dari data diatas dapat diketahui bahwa penderita terbanyak adalah yang berasal dari kediri yaitu sejumlah 56 penderita $(46.67 \%)$.
Tabel 4. Distribusi Daerah Asal Penderita Kusta

\begin{tabular}{lcc}
\hline Daerah asal & Frekuensi & Persentase \\
Kediri & 56 & 46.67 \\
\hline Nganjuk & 24 & 20 \\
\hline Tulungagung & 11 & 9.17 \\
\hline Surabaya & 5 & 4.17 \\
\hline Magetan & 5 & 4.16 \\
\hline Tuban & 4 & 3.33 \\
\hline Blitar & 4 & 3.33 \\
\hline Jember & 3 & 2.50 \\
\hline Ponorogo & 3 & 2.50 \\
\hline Lamongan & 3 & 2.50 \\
\hline Madura & 2 & 1.67 \\
\hline Total & 120 & 100 \\
\hline
\end{tabular}

\section{Distribusi Tipe Kusta Penderita Baru Kusta}

Berdasarkan hasil penelitian, diperoleh data tipe kusta terbanyak adalah kusta tipe multibasiler, yaitu sejumlah 110 penderita $(91.67 \%)$. Kusta tipe pausibasiler terdapat sejumlah 10 penderita $(8.33 \%)$.

Tabel 5. Distribusi Tipe Kusta Penderita Baru Kusta

\begin{tabular}{ccc}
\hline Tipe kusta & Frekuensi & Persentase \\
$\begin{array}{c}\text { Pausibasiler } \\
\text { (PB) }\end{array}$ & 10 & 8.33 \\
$\begin{array}{c}\text { Multibasiler } \\
(\mathrm{MB})\end{array}$ & 110 & 91.67 \\
Total & 120 & 100 \\
\hline
\end{tabular}

\section{Distribusi Gambaran Klinis Penderita Kusta}

Berdasarkan hasil penelitian, diperoleh gambaran klinis yang bervariasi. Terdapat 2 gambaran klinis yang terjadi pada sebagian besar penderita kusta yaitu makula sejumlah 106 penderita $(88.33 \%)$ dan anastesi sejumlah 100 penderita $(83.33 \%)$. Bentuk gambaran klinis yang jarang terjadi pada penderita kusta adalah nodul yaitu sejumlah 3 penderita $(2.50 \%)$. 
Tabel 6. Distribusi Gambaran Klinis Penderita Kusta

\begin{tabular}{lcc}
\hline $\begin{array}{c}\text { Bentuk } \\
\text { gambaran } \\
\text { klinis }\end{array}$ & Frekuensi & Persentase \\
\hline Makula & 106 & 88.33 \\
Anastesi & 100 & 83.33 \\
\hline Infiltrat & 24 & 20 \\
\hline Ulkus & 22 & 18.33 \\
\hline Kulit kering & 8 & 6.67 \\
\hline Lagoftalmus & 5 & 4.17 \\
\hline
\end{tabular}

\section{Distribusi Predileksi Pembesaran Saraf}

Berdasarkan hasil penelitian, predileksi pembesaran saraf terbanyak adalah saraf tibialis posterior dengan ratarata $65.41 \%$ dari total penderita kusta, pada sisi tubuh bagian kanan sejumlah 82 penderita $(68.33 \%)$ dan sisi tubuh bagian kiri sejumlah 75 penderita $(62.50 \%)$.
Distribusi Tingkat Kecacatan Penderita Baru Kusta

Berdasarkan hasil penelitian, tingkat kecacatan pada mata yang terbanyak adalah tingkat 0 atau tidak ada kecacatan dengan persentase $95 \%$ dari total penderita kusta, pada mata kanan sejumlah 113 penderita (94.17\%) dan mata kiri sejumlah 115 penderita (95.83\%). Pada tangan tingkat kecacatan yang terbanyak adalah tingkat 0 dengan persentase $55.41 \%$ dari total penderita kusta, pada tangan kanan 68 penderita $(56.67 \%)$ dan pada tangan kiri sejumlah 65 penderita $(54.16 \%)$. Sedangkan pada kaki, tingkat kecacatan yang terbanyak adalah tingkat 1 yaitu sejumlah 54 penderita (45\%) pada kaki kanan dan 53 penderita $(44.17 \%)$ pada kaki kiri, dengan rata-rata persentase $44.48 \%$.

\section{Distribusi Reaksi Kusta Penderita Baru Kusta}

Berdasarkan data hasil penelitian, mayoritas penderita kusta tidak mengalami reaksi kusta dengan jumlah 95 penderita (79.17\%). Reaksi kusta yang terbanyak adalah reaksi tipe 1 yaitu sejumlah 16 penderita $(14.16 \%)$.

Tabel 7. Distribusi Predileksi Pembesaran Saraf

\begin{tabular}{lccccc}
\hline \multirow{2}{*}{$\begin{array}{c}\text { Predileksi } \\
\text { pembesaran saraf }\end{array}$} & \multicolumn{2}{c}{ Kanan } & \multicolumn{2}{c}{ Kiri } & \multirow{2}{*}{ Rata-rata (\%) } \\
\cline { 2 - 5 } Aurikularis magnus & 47 & 39.17 & 43 & 35.83 & 37.50 \\
\cline { 1 - 5 } Medianus & 40 & 33.33 & 38 & 31.67 & 32.50 \\
\hline Ulnaris & 46 & 38.33 & 46 & 38.33 & 38.33 \\
\hline Radialis & 29 & 24.17 & 28 & 23.33 & 23.75 \\
\hline Peroneus & 21 & 17.50 & 19 & 15.83 & 16.67 \\
\hline Tibialis posterior & 82 & 68.33 & 75 & 62.50 & 65.41 \\
\hline
\end{tabular}

Tabel 8. Distribusi Tingkat Kecacatan Penderita Baru Kusta

\begin{tabular}{cccccc}
\hline \multirow{2}{*}{$\begin{array}{c}\text { Tingkat } \\
\text { kecacatan }\end{array}$} & \multicolumn{2}{c}{ Kanan } & \multicolumn{2}{c}{ Kiri } & Rata-rata (\%) \\
\cline { 2 - 5 } & Frekuensi & Persentase & Frekuensi & Persentase & \\
\hline Tingkat 0 & 113 & 94.17 & 115 & 95.83 & 95 \\
\hline Tingkat 1 & 5 & 4.17 & 2 & 1.67 & 2.92 \\
\hline Tingkat 2 & 2 & 1.66 & 3 & 2.50 & 2.08 \\
\hline & & & Tangan & & \\
\hline Tingkat 0 & 68 & 56.67 & 65 & 54.16 & 25.41 \\
\hline Tingkat 1 & 21 & 17.50 & 26 & 21.67 & 25.58 \\
\hline Tingkat 2 & 31 & 25.83 & 29 & 24.17 & 32.08 \\
\hline Tingkat 0 & 37 & 30.83 & 40 & & 44.58 \\
\hline Tingkat 1 & 54 & 45 & 53 & 43.33 & 23.33 \\
\hline Tingkat 2 & 29 & 24.17 & 27 & 22.50 &
\end{tabular}


Tabel 9. Distribusi Reaksi Kusta Penderita Baru Kusta

\begin{tabular}{rcc}
\hline Reaksi kusta & Frekuensi & Persentase \\
Tidak ada reaksi & 95 & 79.17 \\
\hline Reaksi tipe 1 & 17 & 14.16 \\
Reaksi tipe 2 & 8 & 6.67 \\
Total & 120 & 100 \\
\hline
\end{tabular}

\section{Pembahasan}

Pada penelitian ini diperoleh $120(6.12 \%)$ penderita kusta baru dari total 1960 kunjungan. Jumlah penderita kusta baru ini lebih besar dari tahun 2009, yaitu 104 (3.69\%) penderita kusta baru dari 2812 kunjungan dalam setahun. Hal ini kemungkinan disebabkan oleh peningkatan kejadian kusta seiring bertambahnya tahun, meningkatnya kesadaran masyarakat terhadap kesehatan, dan meningkatnya kesadaran untuk memperoleh pengobatan.

Berdasarkan hasil penelitian, didapatkan jenis kelamin laki-laki sejumlah 90 penderita (75\%), sedangkan perempuan sejumlah 30 penderita (25\%). Jenis kelamin laki-laki lebih banyak daripada perempuan dengan perbandingan 3:1. Hasil tersebut sama dengan penelitian Darmaputra, pada periode tahun 2004-2006 di RSUD Dr. Soetomo Surabaya perbandingan jenis kelamin laki-laki dengan perempuan adalah 3:1. Laki-laki lebih banyak menderita kusta karena laki-laki cenderung lebih sering beraktivitas di luar rumah sehingga kemungkinan risiko tertular kusta lebih besar dari wanita (Darmaputra, 2009). Adanya kecenderungan tidak memakai pakaian di kehidupan sehari-hari pada laki-laki, diyakini meningkatkan kemungkinan risiko tertular kusta melalui kontak kulit (Noorden SK, 1994). Pada penelitian lain disebutkan, laki-laki lebih banyak menderita kusta karena laki-laki kurang memperhatikan kebersihan diri dibandingkan dengan perempuan (Varkevisser, 2009). Berdasarkan dari hasil penelitian di Rumah Sakit Kusta Kediri, jenis kelamin laki-laki lebih banyak menderita kusta $75 \%$ dari total penderita kasus baru. Hal ini kemungkinan karena laki-laki lebih sering bekerja di luar rumah daripada wanita, sehingga meningkatkan risiko tertular kusta. Namun, hal itu juga dipengaruhi oleh lingkungan pekerjaan dan keadaan sosial ekonomi penderita.

Pada penelitian ini diperoleh data penderita usia termuda 5 tahun dan usia tertua 90 tahun. Usia terbanyak adalah usia dewasa dengan rentang usia 35-44 tahun sejumlah 32 penderita $(26.67 \%)$ dan 45-54 tahun sejumlah 21 penderita $(17.50 \%)$, sedangkan kelompok usia paling sedikit yaitu usia anak-anak dengan rentang usia 5-9 tahun sejumlah 1 penderita $(0.83 \%)$ dan usia 10-14 tahun sejumlah 3 penderita $(2.50 \%)$. Dari hasil penelitian tersebut dapat diketahui bahwa penderita kusta usia dewasa lebih banyak daripada penderita usia anak-anak. Hasil tersebut sesuai dengan 2 penelitian kusta oleh Retno dan Darmaputra di RS Dr. Soetomo dalam 2 kurun waktu yang berbeda, dimana penderita kusta usia dewasa lebih banyak daripada penderita usia anak-anak dengan persentase lebih dari 90\% jumlah total penderita baru. Menurut Kumar, insiden kusta meningkat sesuai dengan peningkatan usia. Hal tersebut disebabkan oleh masa inkubasi kusta yang sangat lama dan gambaran klinis dari kusta muncul terlambat (Noorden SK, 1994). Dalam literatur lain disebutkan, usia tua meningkatkan risiko tertular kusta akibat menurunnya sistem imunitas seluler tubuh (Hargrave, 2010). Berdasarkan hasil penelitian di Rumah Sakit Kusta Kediri, penderita usia dewasa lebih banyak daripada penderita usia anak-anak dengan persentase lebih dari $90 \%$. Hal ini disebabkan oleh karena masa inkubasi Mycobacterium leprae yang membutuhkan waktu lama sekitar 40 hari sampai 40 tahun, sehingga gambaran klinis muncul pada usia dewasa.

Kusta lebih banyak diderita oleh penderita dengan keadaan sosial ekonomi rendah (Ghimire, 2000). Keadaan sosial dan ekonomi merupakan salah satu faktor yang mempengaruhi penularan kusta (Kosasih, 2007). Berdasarkan hasil penelitian, jenis pekerjaan terbanyak adalah swasta yaitu sejumlah 52 penderita (43.33\%). Data tersebut kurang spesifik terhadap jenis pekerjaan karena peneliti tidak mengetahui jenis-jenis pekerjaan yang masuk dalam kategori jenis pekerjaan swasta. Petugas rekam medik menjelaskan bahwa data tersebut didapat dari Kartu Tanda Penduduk (KTP) penderita kusta dan sebagian besar penderita kusta dengan kategori pekerjaan swasta ini menyebutkan bahwa pekerjaan swasta adalah pedagang dan pekerja pabrik. Pada penelitian Muchtar di Poliklinik Kulit dan Kelamin RS Dr. Wahidin Sudirohusodo Makassar periode 2002-2003 diperoleh data jenis pekerjaan yang terbanyak adalah petani dengan persentase $57.5 \%$, sedangkan pada hasil penelitian di Rumah Sakit Kusta Kediri jenis pekerjaan petani hanya sebesar $25.83 \%$. Berdasarkan hasil penelitian, terdapat perbedaan distribusi jenis pekerjaan dengan penelitian sebelumnya. Di Kediri tempat dilakukan penelitian ini, jenis pekerjaan yang paling banyak adalah swasta (pedagang dan pekerja pabrik), sedangkan di penelitian lain yang di lakukan di Makassar mayoritas penderita adalah petani. Perbedaan tersebut dapat dipengaruhi faktor geografis dan kemajuan dalam pengembangan kota. Kediri terletak di pulau Jawa, dimana pengembangan kota lebih maju dibandingkan di pulau lain. Kemungkinan kemajuan pengembangan kota dan padatnya penduduk di pulau Jawa mengakibatkan berkurangnya lahan persawahan sehingga jenis pekerjaan petani tidak sebanyak di Makassar.

Dari hasil penelitian diperoleh data tipe kusta terbanyak adalah tipe multibasiler (MB) yaitu sejumlah 110 penderita (91.67\%), sedangkan tipe pausibasiler (PB) sejumlah 10 penderita $(8.33 \%)$. Hasil tersebut sesuai dengan penelitian 
Muchtar di Poliklinik Kulit dan Kelamin RS Dr. Wahidin Sudirohusodo Makassar periode 2002-2003 didapatkan persentase tipe MB yaitu 91.7\%, sedangkan PB 8.3\%. Pada penelitian di RSUD Dr. Soetomo Surabaya periode 20042006 didapatkan hasil yaitu tipe MB sebesar 81.4\% dan tipe PB 18.6\%. Kusta tipe MB lebih banyak daripada tipe PB, karena tipe MB merupakan tipe kusta yang lebih mudah menular dibandingkan tipe PB (Amiruddin, 2003). Tipe MB terjadi pada individu dengan sistem imunitas tubuh yang rendah, biasanya pada individu usia tua (Hargrave, 2010). Berdasarkan hasil penelitian menunjukkan bahwa kusta tipe MB lebih banyak yaitu $91.67 \%$ dari total penderita. $\mathrm{Hal}$ ini kemungkinan karena tipe tersebut mudah menular melalui kontak kulit maupun inhalasi.

Dari penelitian didapatkan data bentuk gambaran klinis terbanyak adalah makula yaitu sejumlah 106 penderita $(88.33 \%)$, diikuti bentuk gambaran klinis anastesi sejumlah 100 penderita $(83.33 \%)$. Beberapa kelainan yang sedikit didapatkan pada penelitian yakni lagoftalmus (4.17\%), madarosis $(3.33 \%)$ dan nodul $(2.50 \%)$. Pada penelitian Darmaputra di RSUD Dr. Soetomo periode 20042006 didapatkan persentase $79.9 \%$ untuk bentuk gambaran klinis makula dan anastesi. Kelainan kulit/makula dan anastesi merupakan tanda awal yang muncul pada penyakit kusta (Pfaltzgraff, 1994). Adanya lagoftalmus dan madarosis merupakan tanda terdapatnya kelainan yang luas pada saraf fasialis dan jaringan disekitar mata (Joffrion, 1994). Kelainan yang terjadi pada penderita kusta umumnya berupa kelainan kulit yang sering tidak dihiraukan oleh penderita. Berdasarkan hasil penelitan di Rumah Sakit Kusta Kediri ini menunjukkan peningkatan kesadaran masyarakat terhadap kesehatan, sehingga masyarakat segera mencari pengobatan ketika terdapat kelainan pada tubuhnya walaupun aktivitas seharihari belum terganggu.

Berdasarkan hasil penelitian, predileksi pembesaran saraf terbanyak adalah saraf tibialis posterior dengan persentase rata-rata $65.41 \%$ dari total penderita kusta baru di Rumah Sakit Kusta Kediri. Pada penelitian Jain di India didapatkan data pembesaran saraf tibialis posterior $57.5 \%$ dari penderita kusta. Besarnya jumlah pembesaran saraf tibialis posterior karena letak saraf tersebut berada di proksimal tubuh yang memiliki suhu lebih rendah daripada suhu inti tubuh, Mycobacterium leprae berkembang biak baik pada suhu yang dingin (Charles, 1994). Pada tubuh bagian atas, dari hasil penelitian didapatkan pembesaran saraf di ulnaris sebesar $38.33 \%$, diikuti pembesaran saraf medianus sebesar $32.50 \%$, kemudian pembesaran saraf di radialis sebesar $23.75 \%$. Pembesaran saraf pada tubuh bagian atas biasanya menunjukkan adanya pola spasiotemporal, jika yang membesar hanya satu saraf biasanya adalah saraf ulnaris, namun apabila saraf medianus yang mengalami pembesaran maka akan diikuti pembesaran saraf ulnaris, dan apabila saraf radialis yang membesar maka akan diikuti pembesaran saraf medianus dan ulnaris (Srinivasan, 1994). Berdasarkan hasil penelitian, menunjukkan bahwa pembesaran saraf lebih banyak terjadi di tubuh bagian bawah atau kaki, kemungkinan ini terjadi akibat dari sifat Mycobacterium leprae yang mudah berkembang biak pada tubuh bagian bawah yang memiliki suhu cenderung lebih dingin dari suhu inti tubuh. Selain itu, kemungkinan pembesaran saraf di kaki lebih mengganggu aktivitas penderita dalam kehidupan sehari-hari daripada pembesaran saraf di bagian tubuh lain sehingga penderita segera mencari pengobatan.

Kecacatan pada penderita kusta dibedakan berdasarkan letak dan tingkat kecacatan. Berdasarkan letak kecacatan dibagi menjadi 3 yaitu kecacatan pada mata, tangan dan kaki, sedangkan berdasarkan tingkat kecacatan terdapat tingkat 0 , tingkat 1 dan tingkat 2. Pada mata, tingkat kecacatan 0 atau tidak ada kecacatan memiliki persentase paling besar yaitu 95\% dari penderita kusta baru. Hasil ini tidak jauh berbeda dengan penelitian Darmaputra yakni sebesar 98.2\%. Kecacatan mata tingkat 1 dan tingkat 2 pada penelitian ini relatif sedikit $(5 \%)$. Sedikitnya kelainan mata yang didapatkan pada penelitian ini kemungkinan disebabkan karena kerusakan pada mata sering tidak tampak dengan jelas, seperti pada kecacatan tingkat 1 dimana belum didapatkan gangguan penglihatan yang berarti (Werdiningsih, 2003). Pada tingkat 2 , terlihat kecacatan yang nampak jelas berupa lagoftalmus. Lagoftalmus terjadi akibat adanya invasi Mycobacterium leprae pada saraf fasialis. Adanya gangguan pada saraf fasialis menyebabkan proses penutupan kelopak mata yang dilakukan oleh otot orbikularis okuli terganggu (Joffrion, 1994).

Berdasarkan hasil penelitian, tingkat kecacatan pada tangan diperoleh data tingkat kecacatan 0 atau tidak ada kecacatan yaitu sebesar 55.41\%. Pada penelitian Darmaputra, tingkat kecacatan pada tangan terbanyak adalah tingkat 0 dengan persentase sebesar $76 \%$. Kecacatan tangan tingkat 1 yang ditandai dengan adanya kerusakan saraf sensoris diperoleh hasil persentase sebesar $19.58 \%$, sedangkan kecacatan tingkat 2 yang ditandai dengan kecacatan yang terlihat nyata diperoleh hasil sebesar 25\%. Adanya kerusakan sensoris ini akibat invasi Mycobacterium leprae pada saraf yang superfisial karena bakteri tersebut berkembangbiak baik pada bagian tubuh yang lebih dingin. Saraf superfisial merupakan bagian yang mudah terkena trauma dari luar dan dapat terjadi infeksi, hal ini yang menyebabkan terjadinya ulkus pada tangan (Charles, 1994).

Pada kaki, tingkat kecacatan yang terbanyak adalah tingkat 1 dengan persentase sebesar $44.58 \%$. Hasil tersebut lebih tinggi dibandingkan dengan penelitian Darmaputra, kecacatan pada kaki tingkat 1 memiliki persentase sebesar 21.4\%. Peningkatan kecacatan tingkat 1 pada kaki kemungkinan terjadi akibat kurangnya kesadaran merawat diri khususnya pada bagian kaki pada penderita kusta serta pengobatan kusta yang terlambat. Kecacatan tingkat 1 atau kerusakan saraf sensoris pada kaki menyebabkan pasien kehilangan kemampuan merasakan nyeri, panas dan raba. Hal tersebut meningkatkan risiko terjadinya ulkus plantaris (Depkes, 2007). Adanya ulkus pada telapak kaki mengganggu penyebaran tekanan pada daerah sekitar sekitar sehingga luka baru menjadi mudah muncul, hal ini memperburuk kondisi cacat kaki penderita (Halim, 2010).

Berdasarkan hasil penelitian ini, kecacatan pada kaki lebih banyak daripada kecacatan pada mata dan tangan. Seperti pada pembahasan mengenai hasil predileksi pembesaran saraf yang lebih banyak terdapat pada saraf tibialis posterior, hal ini kemungkinan terjadi akibat sifat Mycobacterium leprae yang berkembangbiak baik pada bagian 
tubuh yang lebih dingin. Kemungkinan lain yaitu penderita biasanya mencari pengobatan ketika aktivitas sehari-hari mulai terganggu sehingga mengakibatkan terlambatnya pengobatan.

Reaksi kusta muncul selama masa pengobatan atau setelah pengobatan. Penderita dengan reaksi kusta biasanya merupakan penderita rujukan yang mengalami reaksi setelah mendapatkan pengobatan dari puskesmas atau rumah sakit lain (Depkes, 2007). Dari hasil penelitian diperoleh 96 penderita $(80 \%)$ tidak mengalami reaksi kusta, 16 penderita (13.33) reaksi tipe 1 dan 8 penderita (6.67\%) reaksi tipe 2. Berdasarkan data hasil penelitian, menunjukkan penderita yang datang ke Rumah Sakit Kusta Kediri mayoritas tidak mengalami reaksi kusta. Hal tersebut kemungkinan karena penderita di Rumah Sakit Kusta Kediri belum pernah mendapatkan pengobatan.

Reaksi kusta tipe 1 ditandai dengan gambaran klinis makula yang meradang, sedangkan reaksi tipe 2 ditandai dengan adanya nodul dan nodul berulkus. Berdasarkan hasil penelitian, penderita kusta dengan reaksi tipe 2 sejumlah 8 penderita, hasil tersebut berbeda dengan hasil penelitian mengenai distribusi gambaran klinis yang berupa nodul yang didapatkan sejumlah 3 penderita. Hal ini kemungkinan disebabkan karena kesalahan dalam pemeriksaan atau kesalahan dalam pencatatan rekam medik.

\section{KESIMPULAN}

Jumlah penderita baru kusta di Rumah Sakit Kusta Kediri periode Januari 2010 sampai Desember 2010 sebanyak $120(6.12 \%)$ kasus baru dari 1960 kunjungan. Jenis kelamin laki-laki lebih banyak dari perempuan dengan jumlah 90 penderita $(75 \%)$. Kelompok usia terbanyak adalah usia 3544 tahun dengan jumlah sebanyak 32 penderita (26.67\%). Pekerjaan penderita kusta yang terbanyak adalah swasta, yaitu sejumlah 52 penderita (43.33\%). Daerah asal penderita yang terbanyak berasal dari Kediri yaitu 56 penderita (46.67\%). Tipe kusta yang terbanyak adalah tipe MB dengan jumlah 110 penderita (91.67\%). Gambaran klinis kusta terbanyak adalah makula dengan jumlah 106 penderita (88.33\%) dan anastesi sejumlah 100 penderita (83.33\%). Predileksi pembesaran saraf terbanyak terdapat pada saraf tibialis posterior dengan presentase $65.41 \%$. tingkat kecacatan pada mata paling banyak adalah tingkat 0 dengan presentase 95\%. Tingkat kecacatan pada tangan terbanyak tingkat 0 dengan presentase $55.41 \%$. sedangkan tingkat kecacatan pada kaki paling banyak tingkat 1 dengan presentase $44.58 \%$. Reaksi kusta yang paling banyak didapatkan adalah tidak ada reaksi sejumlah 95 penderita $(79.17 \%)$.

\section{DAFTAR PUSTAKA}

Amirudin MD, Hakim Z, Darwis E, 2003, Diagnosis Penyakit Kusta, Dalam: Sjamsoe-Daili ES, Menaldi SL, Ismiarto SR, dkk., Kusta, Edisi Kedua, Balai Penerbit FKUI, Jakarta. Hal.12-31.

Amirudin MD, 2000, Penyakit Kusta, Dalam: Harahap M, Ilmu Penyakit Kulit, Edisi Pertama, Hipokrates, Jakarta. Hal. 260-271.
Brown GR, Burns T, 2002, Lecturer Notes on Dermatology, Erlangga, Jakarta.

Charles KJ, 1994, Pathology of Leprosy, In: Hastings RC, Opromolla DVA, Leprosy, $2^{\text {nd }}$ edition, Churchill Livingstone, Edinburgh. pp. 193-224.

Daili ES, Menaldi SL, Wisnu IM, 2005, Penyakit Kulit yang Umum di Indonesia: Sebuah Panduan Bergambar, PT. Medical Multimedia Indonesia, Jakarta. Hal. 51-59.

Darmaputra IN, Fauzi N, Agusni I, 2009, Kecacatan pada Penderita Kusta Baru di Divisi Kusta URJ Penyakit Kulit dan Kelamin RSUD Dr. Soetomo Surabaya Periode 2004-2006, Berkala Ilmu Kesehatan Kulit dan Kelamin Vol. 21/No. 1/April 2009. Hal. 9-17.

Depkes RI, 2007, Buku Pedoman Nasional Pengendalian Penyakit Kusta, Direktorat Jendral Pengendalian Penyakit dan Penyehatan Lingkungan, Jakarta.

Dinkes Jatim, 2010, Profil Kesehatan Jawa Timur Tahun 2009 http://dinkes.jatimprov.go.id/dokumen/ dokumen_publikasi diakses 15 September 2011.

Ghimire M, 2000, Secondary Deformity in Leprosy: A Socio-Economic

Perspective, Indian Journal of Leprosy. pp. 375-379.

Halim L, Menaldi SL, 2010, Tatalaksana Komprehensif Ulkus Plantar pada Pasien Lepra, Majalah Kedokteran Indonesia, Vol. 60/No. 5/Mei 2010.

Hargrave J, Wallace T, Lush D, 2010, Guidelines for The Control of Leprosy in The Northern Territory, $3^{\text {rd }}$ edition, Departement of Health and Families wmw.nt.gov.au/bealth/ cdc diakses 20 Agustus 2011.

Ishii N, 2003, Recent Advances in The Treatment of Leprosy, Dermatology Online Jurnal Vol. 9 No. 2 , http:// dermatology.cdlib.org diakses 5 Oktober 2011.

Jain S, Visser LH,Praveen, 2009, High-Resolution Sonography: A New Technique to Detect Nerve Damage in Leprosy, PLoS Neglected Tropical Diseases Journal, http:// www.ncbi.nlm.nih.gov/pmc/articles/PMC2716078/ diakses 6 Maret 2012.

Joffrion, 1994, Ocular Leprosy, In: Hastings RC, Opromolla DVA, Leprosy, $2^{\text {nd }}$ edition, Churchill Livingstone, Edinburgh. pp. 353-364.

Kandun NI, 2000, Manual Pemberantasan Penyakit Menular, Edisi 17, Depkes RI.

Kosasih A ,Wisnu IM, Menaldi SL, 2007, Kusta, Dalam: Djuanda A, Ilmu Penyakit Kulit Dan Kelamin, Edisi Kelima, Balai Penerbit FKUI, Jakarta. Hal.73-88.

Kumar A, et al, 2007, Incidence of Leprosy in Agra District, Lepr. Rev. (2007)

78. pp.131-136.

McDougall AC, Yuasa Y, 2005, Atlas Kusta, Sasakawa Memorial Health Foundation, Tokyo.

Muchtar SV, Amiruddin MD, Yogi Y, 2009, Lepromin Test pada Penderita Kusta, Berkala Ilmu Kesehatan Kulit dan Kelamin Vol. 21/No. 1/April 2009. Hal. 18-24.

Mufidah A, Rahimah, 2009, Morbus Hansen, Dalam: Abdullah B, Dermatologi, Edisi Pertama, SMF Ilmu Penyakit Kulit dan Kelamin RSU Haji Surabaya, Surabaya. Hal. 149-159.

Noorden SK, 1994, The Epidemiolpgy of Leprosy, In: Hastings RC, Opromolla DVA, Leprosy, $2^{\text {nd }}$ edition, Churchill Livingstone, Edinburgh. pp. 29-45. 
Pfaltzgraff RE, Ramu G, 1994, Clinical Leprosy, In: Hastings RC, Opromolla

DVA, Leprosy, 2nd edition, Churchill Livingstone, Edinburgh. pp. 237284.

Puspita CG, Widjaja FF, Sopandi SS, 2011, Stigma Towards Leprosy Among Medical Students, Majalah Kedokteran Indonesia Vol. 61, No. 1 http:// indonesia.digitaljournals.org/index.php/ diakses $2 \mathrm{No-}$ vember 2011.

Rea TH, Modlin RL, 2008, Leprosy, In: Wolff K, Goldsmith LA, Katz SI, et al., Fitzpatrick's Dermatology in General Medicine, $7^{\text {th }}$ edition, McGraw-Hill, USA. pp. 1786-1796.

Rees RJW, Young DE, 1994, The Microbiology of Leprosy, In: Hastings RC, Opromolla DVA, Leprosy, $2^{\text {nd }}$ edition, Churchill Livingstone, Edinburgh.

pp. $49-83$.

Soebono H, Suhariyanto B, 2003, Diagnosis Penyakit Kusta, Dalam: SjamsoeDaili ES, Menaldi SL, Ismiarto SR, Kusta, Edisi Kedua, Balai Penerbit FKUI, Jakarta. Hal. 66-74.

Soedarjatmi, Istiarto T, Widagdo L, 2009, Faktor-Faktor Yang Melatarbelakangi Persepsi Penderita Terhadap Stigma Penyakit Kusta, Jurnal Promosi Kesehatan Indonesia Vol.4/No.1/Januari 2009. Hal. 18-24.

Srinivasan H, 1994, Disability, Deformity and Rehabilitation, In: Hastings RC, Opromolla DVA, Leprosy, $2^{\text {nd }}$ edition, Churchill Livingstone, Edinburgh.

pp. 411-447.

Varkevisser CM, Lever P, 2009, Gender and Leprosy: Case Studies in Indonesia, Nigeria, Nepal and Brazil, Lepr. Rev. (2009) 80. pp. 65-75.

Werdiningsih R, Agusni I, 2003, Kecacatan pada Penderita Kusta Baru di Divisi Kusta URJ Penyakit Kulit dan Kelamin RSUD Dr. Soetomo Surabaya Periode 1998-2000, Berkala Ilmu Kesehatan Kulit dan Kelamin Vol. 15/No. 3/Desember 2003. Hal. 149158.

WHO, 1997, $7^{\text {th }}$ WHO Expert Committee on Leprosy, www.who.int/lep/exp diakses 17 Oktober 2011.

WHO, 2010, Global Leprosy Situation, In: Weekly Epidemiological Record, http:// www.who.int/wer diakses 9 April 2011.

Wolff K, Johnson RA, 2009, Fitzpatrick's Color Atlas \& Synopsis of Clinical Dermatology, $6^{\text {th }}$ edition, McGraw-Hill, USA. pp. 665-661. 